\title{
Historical ecology of a biological invasion: the interplay of eutrophication and pollution determines time lags in establishment and detection
}

\author{
Paolo G. Albano • Ivo Gallmetzer • Alexandra Haselmair • Adam Tomašových • \\ Michael Stachowitsch $\cdot$ Martin Zuschin
}

Received: 17 May 2017 / Accepted: 18 November 2017 / Published online: 24 November 2017

(C) The Author(s) 2017. This article is an open access publication

\begin{abstract}
Human disturbance modifies selection regimes, depressing native species fitness and enabling the establishment of non-indigenous species with suitable traits. A major impediment to test the effect of disturbance on invasion success is the lack of long-term data on the history of invasions. Here, we overcome this problem and reconstruct the effect of disturbance on the invasion of the bivalve Anadara transversa from sediment cores in the Adriatic Sea. We show that (1) the onset of major eutrophication in the 1970s shifted communities towards species tolerating hypoxia, and (2) A. transversa was introduced in the 1970s but failed to reach reproductive size until the late 1990s because of metal contamination, resulting
\end{abstract}

Electronic supplementary material The online version of this article (https://doi.org/10.1007/s10530-017-1634-7) contains supplementary material, which is available to authorized users.

P. G. Albano $(\bowtie) \cdot$ I. Gallmetzer · A. Haselmair .

M. Zuschin

Department of Palaeontology, University of Vienna,

Althanstrasse 14, 1090 Vienna, Austria

e-mail:pgalbano@gmail.com

A. Tomašových

Geological Institute, Slovak Academy of Sciences,

Dúbravska Cesta 9, 84005 Bratislava, Slovak Republic

M. Stachowitsch

Department of Limnology and Bio-Oceanography, Center of Ecology, University of Vienna, Althanstrasse 14,

1090 Vienna, Austria in an establishment and detection lag of $\sim 25$ years. Subfossil assemblages enabled us to (1) disentangle the distinct stages of invasion, (2) quantify time-lags and (3) finely reconstruct the interaction between environmental factors and the invasion process, showing that while disturbance does promote invasions, a synergism of multiple disturbances can shift selection regimes beyond tolerance limits and induce significant time lags in establishment. The quantification of these time lags enabled us to reject the hypothesis that aquaculture was an initial vector of introduction, making shipping the most probable source.

Keywords Time lags · Establishment $\cdot$ Hypoxia · Sediment contamination - Anadara transversa . Adriatic Sea

\section{Introduction}

Anthropogenic disturbance is one of the major drivers of biological invasions (Elton 1958; Cohen and Carlton 1998; Occhipinti-Ambrogi and Savini 2003; Crooks et al. 2011). Severe human-driven disturbances are fast events relative to rates of evolutionary adaptations and can shift selection regimes to conditions different from those in which native species evolved, typically reducing their fitness. In contrast, some non-indigenous species (NIS) may be more 
adapted to the recipient disturbed conditions, managing to settle and thrive better than competing native species (the "selection regime modification" mechanism, Byers 2002).

Disturbance, however, plays different roles during the multi-stage invasion process. On one hand, it can favor NIS at the introduction stage but, on the other hand, their persistence can be better in low-disturbance conditions (Clark and Johnston 2011). Untangling the selectivity of environmental conditions on invasions thus requires tracing them over longer periods and at fine-scale temporal resolution. Additionally, the interplay of more than one type of disturbance is rarely directly addressed: experiments usually focus on a single causative factor, and detailed observations often begin only after NIS are already established. The result is that little knowledge is available on the factors that influence establishment success.

The study of biological invasions over ecological time scales is hampered by the lack of long-term data on the temporal variation of communities and environmental factors. A unique but under-exploited source of such information is death and subfossil assemblages formed by skeletal remains in sediments (Dietl and Flessa 2011; Kidwell and Tomašových 2013; Dietl et al. 2015; Kosnik and Kowalewski 2016). These assemblages accumulate information on community states over time, and geochronological and paleoecological methods can be used to reconstruct the history of biological invasions and test hypotheses on the mechanisms behind the invasion process.

Here, we test whether the late 20th-early 21 st century occurrence of hypoxic events driven by human-induced eutrophication in the northern Adriatic Sea (Justić 1991; Giani et al. 2012) shifted the selection regime in favor of hypoxia-tolerant species and facilitated the establishment of the hypoxiatolerant invasive bivalve Anadara transversa (Say, 1822). This is one of the most invasive species in the Mediterranean Sea (Streftaris and Zenetos 2006). Its native range is eastern and southern North America (Albano et al. 2009); it was first detected in the Mediterranean Sea in Izmir (Turkey) in 1977, in Thessaloniki (Greece) in 1993 and then simultaneously along a 200-km coastline from Venice to Ancona in the northern Adriatic Sea in 2000 (Morello and Solustri 2001; Rinaldi 2001; Mizzan 2002). The sudden occurrence of large populations of large-sized specimens over a 200-km-long coastline cannot be explained by the simultaneous introduction of propagules, suggesting a longer introduction history.

The northern Adriatic is a hotspot of NIS introductions (Ghisotti and Rinaldi 1976; Crocetta 2011, 2012; Occhipinti-Ambrogi et al. 2011) and belongs to the ca. 400 so-called dead zones in the world combining most features that characterize coastal ecosystems sensitive to low oxygen events (Riedel et al. 2012, 2014). It is also subject to riverine input from one of the most anthropized and industrialized European drainage basins and, therefore, it is the ideal setting for testing the relationship between multiple disturbances and invasions.

\section{Methods}

Study area and sampling

This study is based on sediment cores collected at two stations located off the Po river delta (Fig. 1) in the northern Adriatic Sea: station $1\left(44^{\circ} 43^{\prime} 50^{\prime \prime} \mathrm{N}, 12^{\circ} 26^{\prime}\right.$ $\left.25^{\prime \prime} \mathrm{E},-21 \mathrm{~m}\right)$ and $2\left(44^{\circ} 50^{\prime} 32^{\prime \prime} \mathrm{N}, 12^{\circ} 32^{\prime} 20^{\prime \prime} \mathrm{E}\right.$, $-23 \mathrm{~m})$. The substrate is muddy at both stations. At each station, two 160-mm-diameter, 150-cm-long cores were taken using an UWITEC $^{\circledR}$ piston corer with hammer action and interchangeable core tube units (Gallmetzer et al. 2016). A third 90-mmdiameter core of the same length was used for sediment dating, grain size and geochemical analyses.

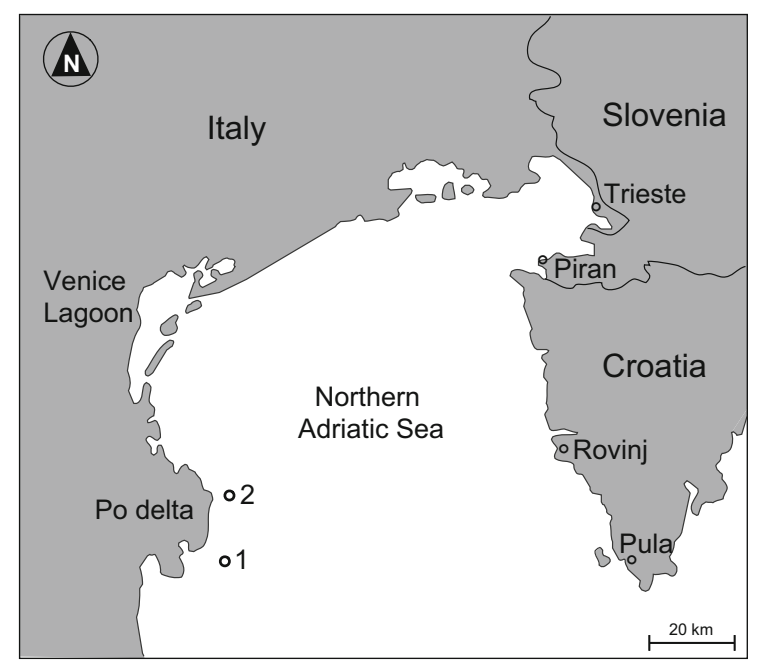

Fig. 1 Position of the two stations off the Po river delta 
Sample processing

Core subsamples were sieved with a minimum mesh size of $1 \mathrm{~mm}$. Molluscan shells were identified to species level and counted. Length (i.e., antero-posterior size) was measured in A. transversa and four other native bivalve species with abundance $>50$ specimens/station: Nucula nucleus (Linnaeus, 1758), Abra alba (W. Wood, 1802), Abra nitida (O.F. Müller, 1776) and Corbula gibba (Olivi, 1792). Abra data were pooled, given that the two species attain comparable lengths in the Adriatic Sea and share a similar natural history.

The reproductive length of Anadara transversa was $10 \mathrm{~mm}$ in a study conducted in Georgia, USA (Walker and Power 2003). The seawater temperature in the northern Adriatic Sea is slightly lower than in Georgia, potentially causing an increase in reproductive length (Strathmann 1987). Nonetheless, the increases in individual and population sizes are so well marked (Fig. 2) that such variation does not influence our interpretation. Because no information is available for $N$. nucleus, we used data on $N$. nitidosa, which has a similar maximum size and life span. This species is likely sexually mature after $1-2$ years; we considered $5 \mathrm{~mm}$ as reproductive size because the species attains a size of ca. 3-4 mm after 1 year and then grows $1 \mathrm{~mm} /$ year (Rachor and Salzwedel 1976). The first reproductive cycle of Abra alba occurs at a length of ca. $8 \mathrm{~mm}$ in the Western English Channel (Dauvin and Gentil 1989). The reproductive size of Corbula gibba has surprisingly-considering its abundance across the entire northern Adriatic and its hypoxia and disturbance tolerance (Occhipinti-Ambrogi et al. 2002; Holmes and Miller 2006; Nerlović et al. 2011) — not been studied so far. The species attains a length of $3 \mathrm{~mm}$ at the age of one year (Jensen 1990). Because of the presumed life-span of 2 to 5 years (Jensen 1990; Hrs-Brenko 2006), we hypothesize a 1 -year generation time and thus a reproductive size of $3 \mathrm{~mm}$.

Geochronology and sediment analyses

The age of sediment layers was quantified using two independent methods: ${ }^{210} \mathrm{~Pb}$ radiometric sediment dating and radiocarbon calibrated amino acid racemization dating (AAR) of bivalve shells. These two approaches have entirely distinct assumptions and potential biases, making them well suited for crossvalidation.

The ${ }^{210} \mathrm{~Pb}$ analysis was performed at the Low-Level Counting Labor Arsenal at the University of Natural Resources and Life Sciences in Vienna. Activities of ${ }^{210} \mathrm{~Pb}$ and ${ }^{226} \mathrm{Ra}$ were analyzed in 2 -cm-thick intervals in the upper $20 \mathrm{~cm}$ and in 5-cm-thick intervals between 20 and $40 \mathrm{~cm}$ by gamma spectrometry using a High Purity Germanium detector system. We computed apparent sediment-accumulation rates from the slope of the decay in excess ${ }^{210} \mathrm{~Pb}$ according to the Constant Flux-Constant Sedimentation model (CFCS, Sanchez-Cabeza and Ruiz-Fernández 2012). We avoided the surface mixed layer (SML), which corresponds to the top $20 \mathrm{~cm}$, within which excess ${ }^{210} \mathrm{~Pb}$ levels remain approximately constant.

Amino acid racemization (AAR) dating is based on the inter-conversion between the two configurations of amino acids: left (L) and right (D) handed (see (Miller et al. 2013) for a recent review of the method). AAR was analyzed on 495 specimens of $C$. gibba selected from 14 increments in the core Po 3 (with midpoints at $2,6,10,14,18,22.5,42.5,67.5,82.5,97.5,107.5$, $112.5,132.5$, and $137.5 \mathrm{~cm})$ and 14 increments in the core Po 4 (with midpoints at 2, 6, 10, 14, 18, 32.5, 47.5, $62.5,77.5,92.5,107.5,127.5,132.5$, and $152.5 \mathrm{~cm}$ ). AAR analysis was carried out at Northern Arizona University using reverse-phase high-pressure liquid chromatography (RP-HPLC) and the procedures of Kaufman and Manley (1998). Seventeen specimens were flagged as outliers according to screening criteria outlined by Kosnik and Kaufman (2008), and the 243 shells from station 1 and the 252 shells from station 2 were used for dating. Eleven shells dated by ${ }^{14} \mathrm{C}$ and three live-collected shells were used for calibration of amino acid racemization rates to calendar years, using the time-dependent reaction kinetic model (Allen et al. 2013) for Asp $\mathrm{D} / \mathrm{L}$, with the initial $\mathrm{D} / \mathrm{L}$ value estimated from data (TDK1), and lognormal uncertainty (see Tomašových et al. 2017 for details). Sediment ages were plotted against median shell ages to compare chronologies in 10-cm layers. When no shells were dated in a layer, the layer age was estimated by linear interpolation from the layers above and below.

The grain size of 36 samples was analyzed using a Sedigraph for the small fractions $(<63 \mu \mathrm{m})$ and sieving for larger fractions. The sediments were classified according to Shepard's classification 

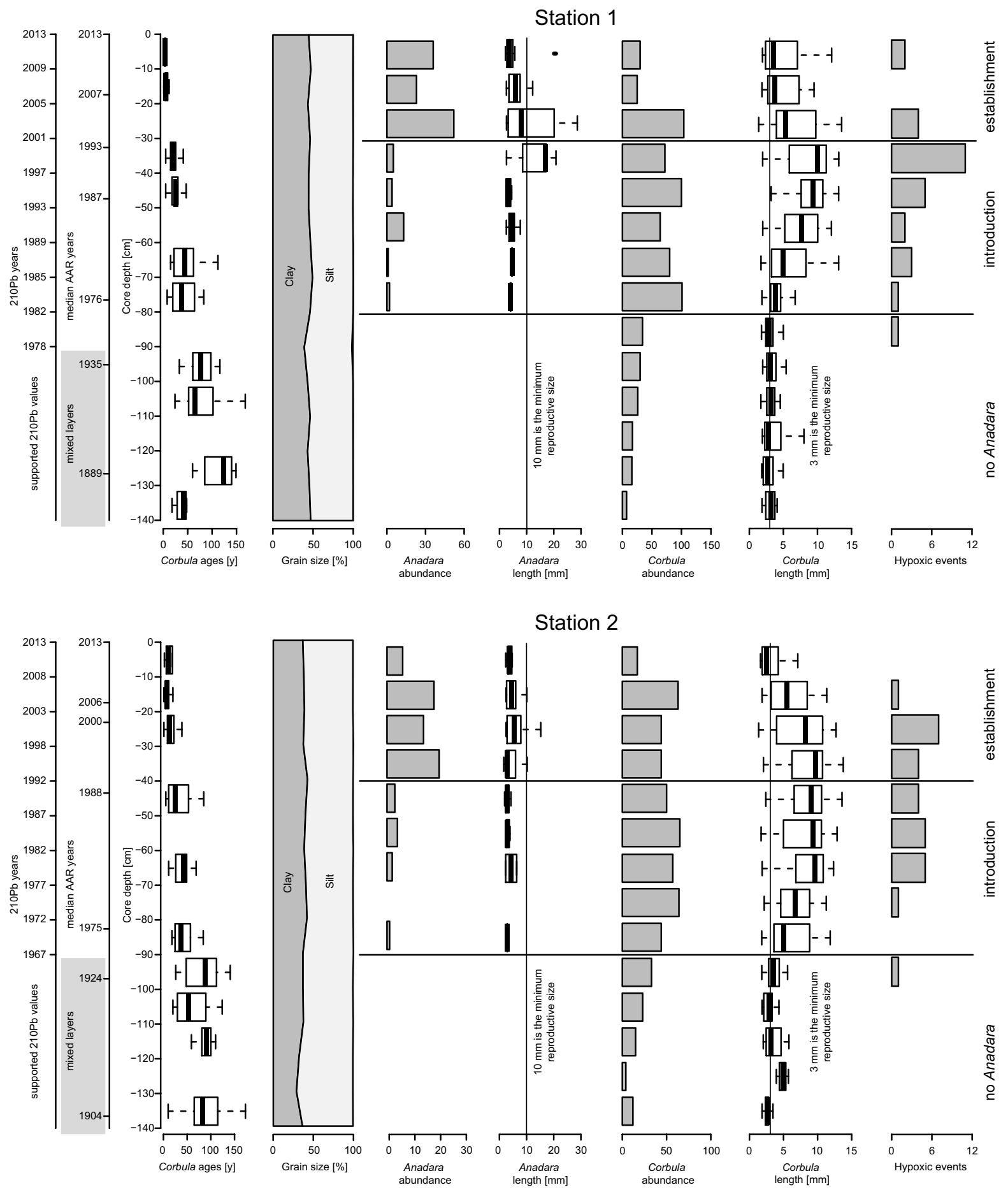

Station 2

(1954). Pollutant concentrations were determined at these core depths: 5, 9, 19, 27, 37, 49, 71, 84, 87, 97, $116,135 \mathrm{~cm}$ and $1,5,9,14,27,38,51,67,81,101$,
$119 \mathrm{~cm}$ at stations 1 and 2, respectively. Geochemical analyses included the content of major $(\mathrm{Fe}, \mathrm{Al})$, minor $(\mathrm{Mn}, \mathrm{P}$ ) and trace elements (As, $\mathrm{Cd}, \mathrm{Cr}, \mathrm{Cu}, \mathrm{Hg}, \mathrm{Ni}$, 
४Fig. 2 Core stratigraphy; from left to right: sediment and Corbula gibba ages (years A.D.), time-averaging quantification (inter-quartile ranges of Corbula gibba ages), sediment structure, target species' abundance (number of individuals) and size, and number of hypoxic events per year after Djakovac et al. (2015) and Justić (1991). ${ }^{210} \mathrm{~Pb}$ and median shell ages in grey areas suggest sediment mixing. Vertical lines mark the bivalves' reproductive size (10 and $3 \mathrm{~mm}$, respectively). At both sites, the first occurrence of Anadara transversa (Say, 1822) is in the 1970s, 20-30 years earlier than the first record in 2000. Between the 1970s and 2000, the species hardly grew larger than $10 \mathrm{~mm}$ and thus did not reproduce. At larger sizes in the late 1990s, reproduction started and population size increased, triggering the first detection in 2000. Since the early 1970s, hypoxic events promoted the hypoxia-tolerant Corbula gibba (Olivi, 1792). A. transversa is hypoxia-tolerant too, but its introduction was delayed by a peak of metal contamination in the sediments (see Fig. 4)

$\mathrm{Pb}, \mathrm{Zn}$ ) and persistent organic pollutants (polycyclic aromatic hydrocarbons-PAH, polychlorinated biphenyls-PCB). The detailed analytical protocol is available in Appendix S1.

Raw concentrations were compared to NOAA sediment quality criteria: effects range low (ER-L), representing the threshold level below which effects on benthic organisms rarely occur, and effects range medium (ER-M), above which effects are likely to occur (Burton 2002).

Hypoxic events and sea temperature

The number of hypoxic events [dissolved oxygen $<2 \mathrm{mg} / \mathrm{l}$, (Diaz and Rosenberg 1995)] per year and the dissolved oxygen at the bottom from 1972 to 2012 were taken from Djakovac et al. (2015). Their stations SJ101 and SJ108 are close to our stations 2 and 1, respectively. Although the surveys of dissolved oxygen concentrations prior to 1972 were collected by variable methods, no hypoxic events were reported between 1911 and 1972 (Justić 1991).

Historical sea surface and bottom temperature data for the Adriatic Sea were obtained from the 1955-2014 Mediterranean Sea physics reanalysis provided by the Copernicus Marine Service Information system (http://marine.copernicus.eu/servicesportfolio/access-to-products/?option=com_csw\&view =details\&product_id=MEDSEA_REANALYSIS_PHY_ 006_009). The dataset has monthly means of physical parameters with a spatial resolution of $0.06 \times 0.06$ degrees and 72 water depth levels.
The native range of $A$. transversa was compiled from the literature (Mikkelsen and Bieler 2008). The sea surface temperature along this range was obtained from the Coastal Water Temperature Guide of the NOAA National Centers for Environmental Information (https://www.nodc.noaa.gov/dsdt/cwtg/index. html, last access December 2016).

\section{Down-core analysis}

Down-core variation of abundance, size, pollutants, community composition and structure was assessed focusing on three intervals: (1) layers without $A$. transversa in the lower part of cores; (2) layers in the middle part of cores where A. transversa appeared, but was represented by juveniles and abundance was low (introduction stage), and (3) upper layers where $A$. transversa was abundant (establishment stage).

Differences in the whole molluscan community composition in the three stages of invasion were assessed with non-metric multidimensional scaling (NMDS) plots (Kruskal and Wish 1978) and permutational multivariate analysis of variance (PERMANOVA, (McArdle and Anderson 2001; Anderson 2001) based on Bray-Curtis dissimilarities on squareroot transformed proportional abundances of molluscan species. Sequential Bonferroni correction was applied to assess significance of pair-wise comparisons $(p=0.05)$. The Similarity Percentage (SIMPER) routine was used to assess the greatest contributors to differences among the three stages (Clarke 1993).

\section{Results}

Sediment ages and mixing

Sedimentation rates based on excess ${ }^{210} \mathrm{~Pb}$ profiles below the surface mixed layer $(0-20 \mathrm{~cm})$ were $2.3 \mathrm{~cm} /$ year and $2.2 \mathrm{~cm} /$ year at stations 1 and 2 , respectively. Shell median ages show that the top $20 \mathrm{~cm}$ correspond to $\sim 2006-2013$ A.D. and the interval from 20 to $90 \mathrm{~cm}$ to the late 20th century after 1950 A.D. with good stratigraphic order. The lower part of the cores corresponds to the early 20th century, with some degree of stratigraphic disorder in the distribution of $C$. gibba ages. ${ }^{210} \mathrm{~Pb}$-based estimates of dates assume constant sedimentation rates and tend to 
be biased upward by bioturbation (Johannessen and Macdonald 2012), whereas AAR estimates of dates can be biased upward or downward by temporallyvariable production of shell producers (Tomašových et al. 2015). In addition, mismatches between these methods can be increased by differential mixing of sediment particles varying in size and durability (Barker et al. 2007). Nonetheless, the dates based on both methods highly correlate (Pearson $r>0.8$ at both stations, $p<0.0001$ ) and show a relatively good correspondence along a one-to-one line.

\section{Down-core occurrence of Anadara transversa}

We found 136 and 76 valves of A. transversa at station 1 and 2 , respectively. At both stations $(\sim 15 \mathrm{~km}$ apart), A. transversa first appeared at $80-90 \mathrm{~cm}$, where the median age of $C$. gibba dates back to 1976 (Fig. 2). In the layers immediately above those of the first occurrence, A. transversa was scarce $(<5$ specimens per layer) and small (rarely exceeding $5 \mathrm{~mm}$ ). This size corresponds to a post-metamorphic life span of days (Walker and Power 2003). Abundance then increased by an order of magnitude and shell length exceeded the reproductive size (>10 mm) in layers dating back to the late 1990s (between 30 and $40 \mathrm{~cm}$ sediment depth). Above 30-40 cm (since 2000 to present), abundance and size remained at high values.

Down-core variation in abundance and size of native species

The three stages of the Anadara invasion process corresponded to distinct molluscan assemblage states in the multivariate compositional space (Fig. 3; PERMANOVA, global $\mathrm{F}=5.7$ and 4.5, $p<0.001$ at both stations, pairwise comparisons in Table S1). The magnitude and significance of differences remain when abundances of Anadara are excluded from analyses (Fig. 3), showing that these temporal differences are driven by the variation in relative abundance of some key native species (SIMPER, Table S2).

During the introduction stage, the abundance of Nucula nucleus and Abra spp. declined markedly compared to the layers before the onset of the introduction. N. nucleus and Abra spp. partly recovered during the establishment stage of A. transversa. C. gibba increased considerably during the introduction stage and remained the dominant species also in the upper layers related to the final, establishment stage. The low abundance of N. nucleus and Abra spp. during the introduction stage was associated with rarity of juveniles, whereas their high abundance during the pre-introduction and establishment stages corresponded with frequent juveniles (Fig. 5). C. gibba increased in size during the introduction stage.

Down-core variation in environmental factors and contaminants

Sediment grain size did not change down-core. The silt plus clay content was $99.7 \% \pm 0.1$ and $99.3 \% \pm 0.1$ at stations 1 and 2 , respectively (Fig. 2). The corresponding percentage of clay were $45.7 \pm 0.5$ and $37.7 \pm 0.8$. Since 1955 -most of the time-frame captured by the cores-water temperature at the sampled water depths showed no significant trend. In contrast, sea surface temperature has increased, especially since 1980 (Fig. S1), but this variation is well within the boundaries derived from sea surface water temperature along A. transversa's native range (Fig. S2). Since the early 1970s, hypoxic events occurred with increased frequency and intensity until $\sim 2005$ (Fig. 2). The number of hypoxic events per layer time interval positively correlates with C. gibba abundance and median size. $A$. transversa abundance correlates weakly and its size does not correlate with the number of hypoxic events (Table S3).

During the introduction stage, a distinct peak of sediment contamination by $\mathrm{Hg}, \mathrm{Ni}, \mathrm{Cr}, \mathrm{Pb}, \mathrm{Zn}$ is detectable (Fig. 4). Especially in the middle part of the cores representing the period from the 1970s to 1990s, $\mathrm{Hg}$ concentration was above the NOAA ER-M level $(0.7 \mathrm{ppm} \mathrm{dw})$ and reached a maximum of $1.34 \mathrm{ppm}$ $\mathrm{dw}$ at $70 \mathrm{~cm}$ at station 1 and of $0.94 \mathrm{ppm}$ dw at 80 and $50 \mathrm{~cm}$ at station 2 (Fig. 5). Nickel also exceeded the ER-M level of $51.6 \mathrm{ppm} \mathrm{dw}$ all along the cores. Chromium and $\mathrm{Zn}$ had values only slightly above ER$\mathrm{L}$, whereas $\mathrm{Pb}$ values were below ER-L. The patterns of overall contamination and the absolute values of contaminants are consistent at the two stations. 

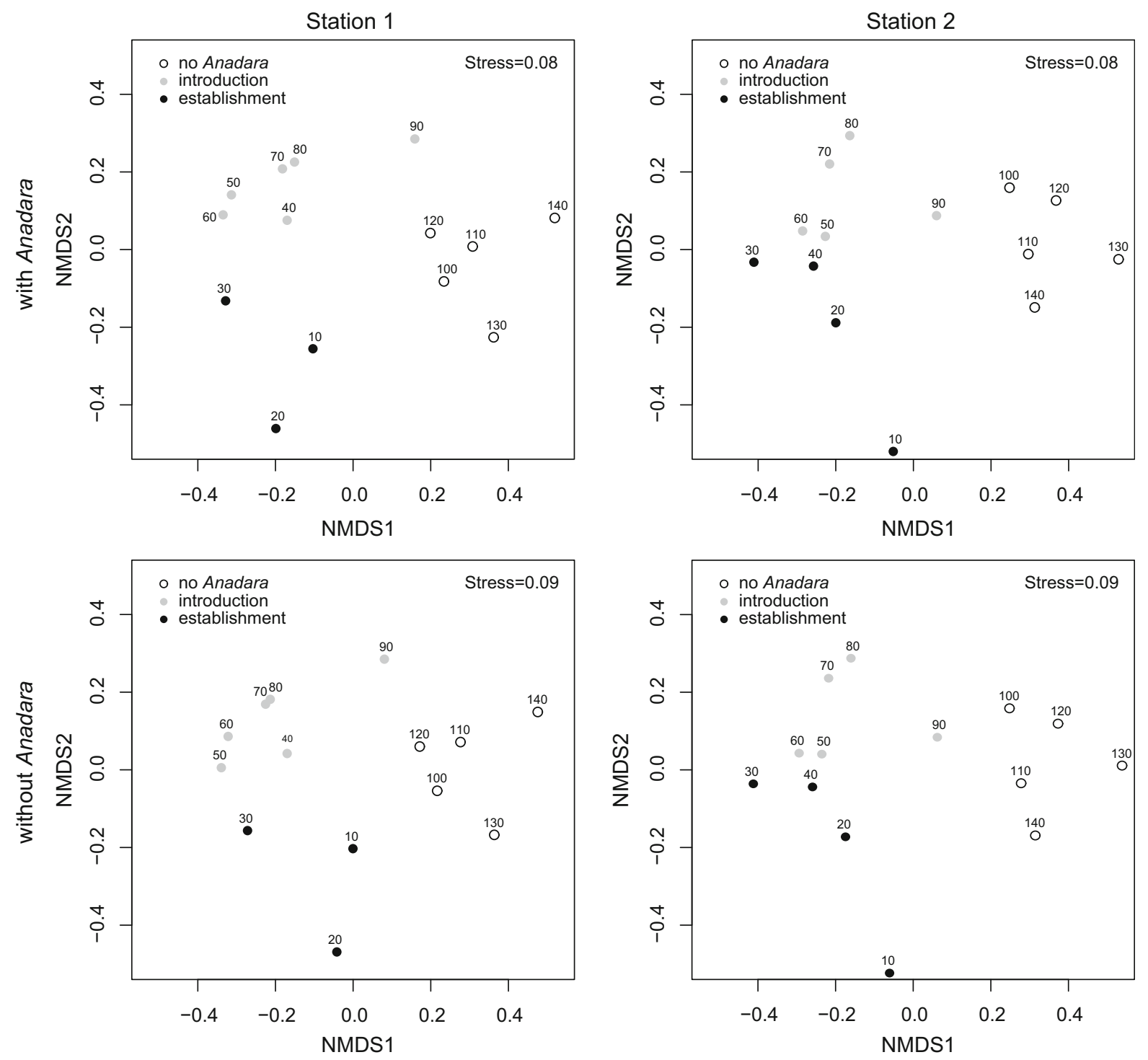

Fig. 3 Nonmetric multidimensional scaling plots of down-core assemblages with the full dataset and without the nonindigenous Anadara transversa (Say, 1822). The three stages in the introduction of $A$. transversa correspond to distinct states

in the molluscan assemblage composition and structure. The identical results with and without $A$. transversa suggest that the assemblages changed irrespective of its introduction

\section{Discussion}

Hypoxia and pollution drove the invasion process

Hypoxic events exert a strong effect on benthic assemblages, preferentially affecting larger, longlived species and promoting hypoxia-tolerant or opportunistic short-lived species (Diaz and Rosenberg 1995). The assemblages off the Po delta responded to the increased occurrence and severity of hypoxia

starting in the 1970s (Justić 1991), profoundly changing their composition (Fig. 3, upper panels) as also observed elsewhere in the northern Adriatic (Crema et al. 1991; Chiantore et al. 2001; Occhipinti-Ambrogi et al. 2005; Kowalewski et al. 2015; Gallmetzer et al. 2017). The hypoxia-tolerant Corbula gibba thrived: its abundance and median size increased in the early 1970s, reaching two to three times the values typical of the early 20th century. Such changes were not driven by the introduction of Anadara transversa, because 

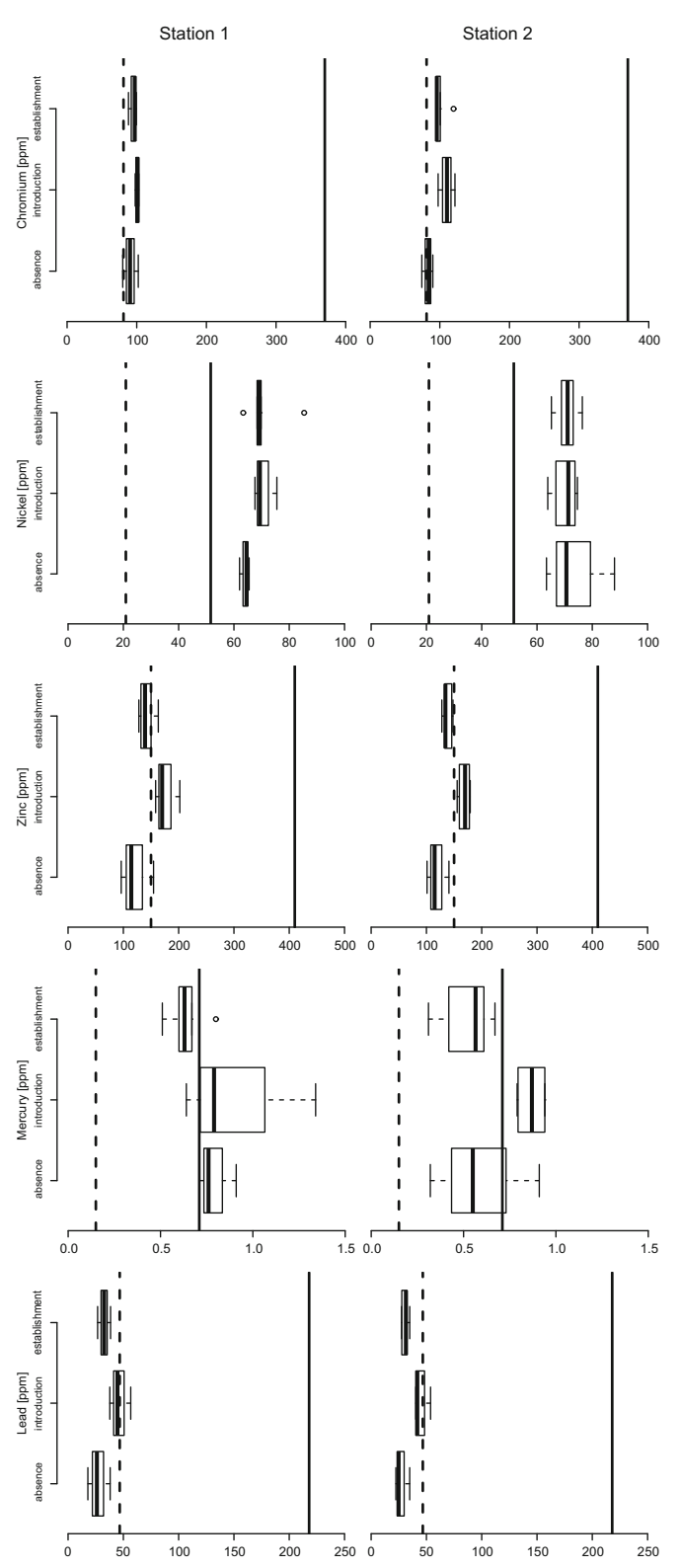

Fig. 4 Bar plots of contaminant concentrations. The dashed line is the NOAA ER-L limit (threshold below which effects rarely occur), the solid line is the NOAA ER-M limit (threshold above which effects are likely to occur)

the NMDS plots are virtually identical if the species is removed from the dataset (Fig. 3, lower panels).

This new selection regime, unprecedented since the early 20th century, should have facilitated the establishment of hypoxia-tolerant non-native species such as A. transversa because Anadarinae possess hemoglobin and erythrocytes in the blood and are thus
Fig. 5 Down-core variation in abundance and shell size of the native bivalves Nucula nucleus (Linnaeus, 1758) and Abra spp. From left to right: sediment and Corbula gibba ages (years A.D.), target species' abundance (number of individuals) and size, down-core variation of mercury concentration in the sediment. ${ }^{210} \mathrm{~Pb}$ and AAR Median shell ages in grey areas suggest sediment mixing occurs. Horizontal lines demarcate the three stages of Anadara transversa (Say, 1822) invasion. The vertical lines mark the bivalves' reproductive size $(5$ and $8 \mathrm{~mm}$, respectively). N. nucleus and Abra spp. experienced a prolonged lack of juveniles that resulted in a population decline corresponding to the time of increased mercury contamination

resistant to hypoxia (Broom 1985). However, since its arrival in the mid-1970s and for the following 25 years, A. transversa failed to establish notwithstanding continuous propagule input, as evidenced by the constant presence of juvenile shells in the sediments.

We found that the introduction stage was also marked by the rarity of juveniles of locally abundant species such as Nucula nucleus and Abra spp. in death assemblages, suggesting that environmental factors negatively affected their reproduction or recruitment. Although hypoxia can affect bivalve larval settlement (Weis 2014), this is unlikely to occur in both $N$. nucleus and Abra spp. because they spawn in late autumn and winter, i.e., after the occurrence of seasonal hypoxic crises (Chardy et al. 1984; Dauvin and Gentil 1989).

Instead, during the introduction stage we detected a peak of sediment contamination by several metals with a particular prevalence of $\mathrm{Hg}$, whose concentrations were above NOAA ER-L, i.e., adverse effects are likely to occur. Mercury negatively affects bivalve burrowing behavior at concentrations of $0.46 \mathrm{ppm}$ (McGreer 1979), but its effects may be more severe for the settlement and survival of larvae and juveniles, the most sensitive life stages, and affect recruitment (McGreer 1982; Bryan and Langston 1992; Boening 2000). Other metals can also negatively affect bivalves. For example, $\mathrm{Zn}$ and $\mathrm{Cu}$ concentrations lower than those we detected slowed burial in the tellinid Macomona liliana (Roper et al. 1995). Metals affect embryonic development, leading to abnormal embryos, and larvae may be even more sensitive than embryonic stages of the same organism because embryos are protected by an outer membrane that may reduce contaminant uptake (Weis 2014). This 
Station 1

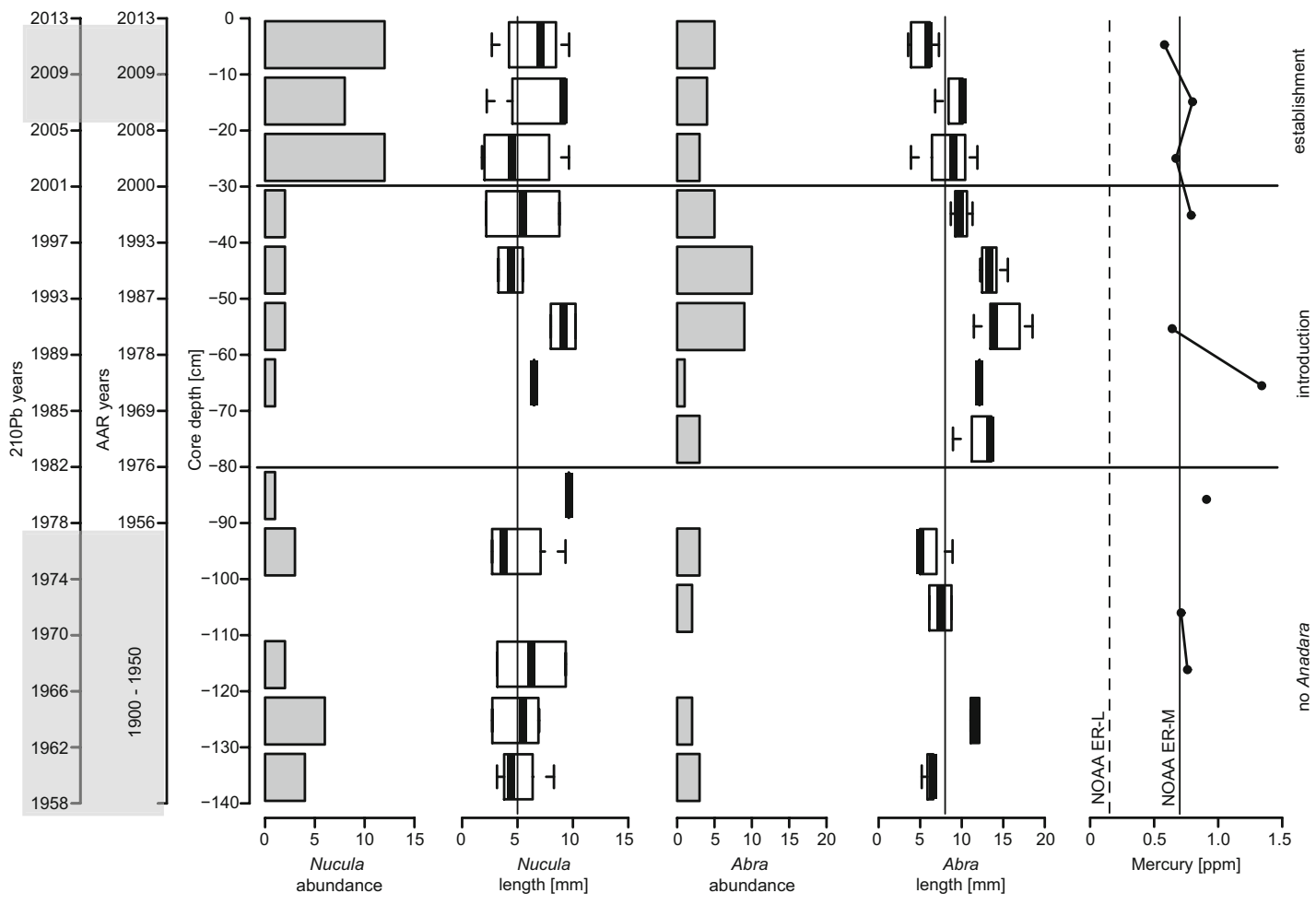

\section{Station 2}

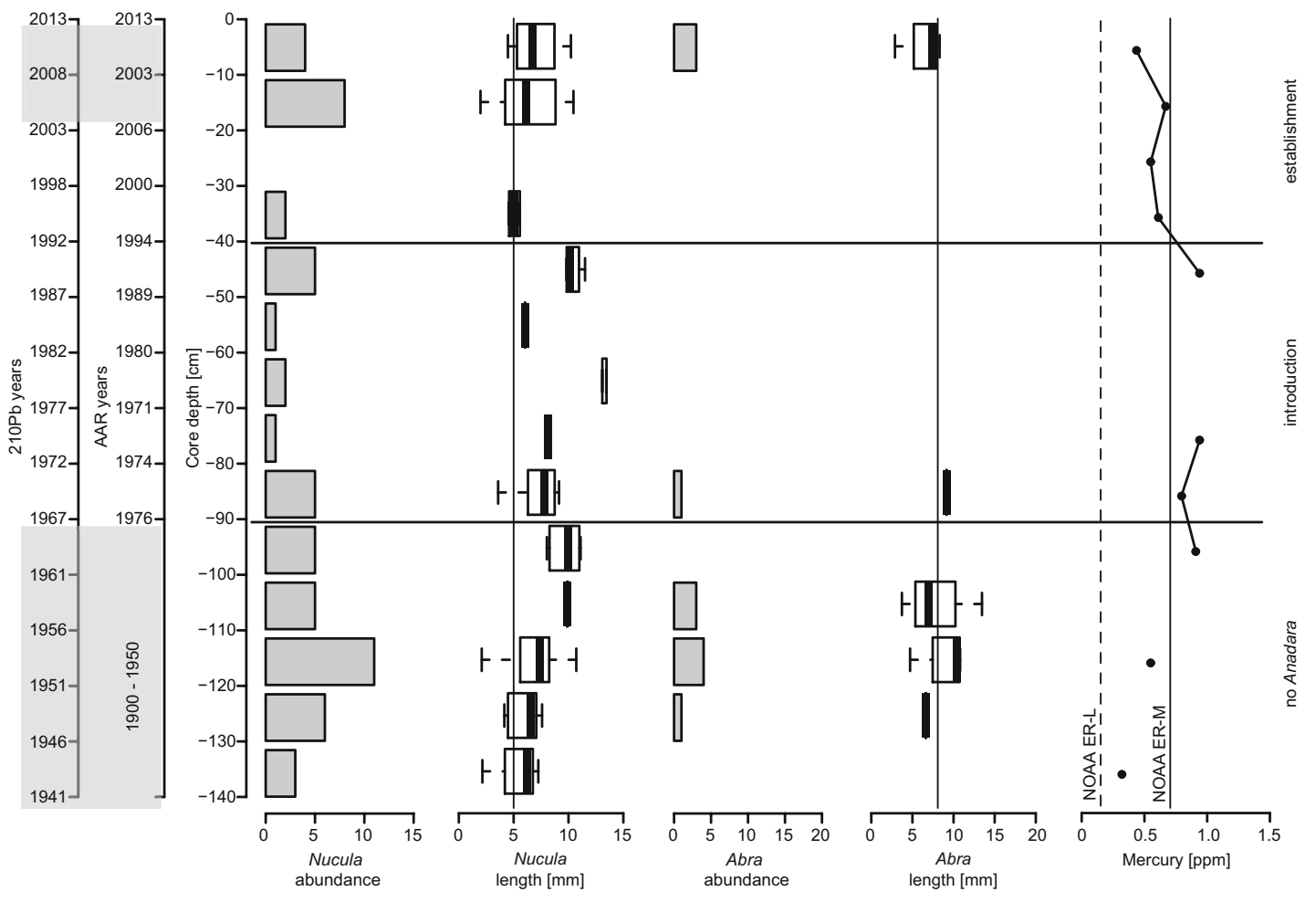


contamination may explain why A. transversa larvae, likely introduced with ballast water from distant parent populations, were affected: larval exposures to contaminants can impair settlement in the benthic environment and/or delay physiological development as juveniles or adults. This would explain the occurrence of only very young $A$. transversa during the introduction phase. Therefore, in contrast to previous findings where pollution preferentially affected native species (Piola and Johnston 2008; Varó et al. 2015), this contamination prevented the establishment of $A$. transversa. Sediment contamination may therefore interfere with the expectation that hypoxic events enhance the success of invasive species in marine and estuarine ecosystems (Byers 2000; Jewett et al. 2005; Lagos et al. 2017). Then, the decline of metal contamination in the early 2000s generated a new selection regime in which hypoxic events and other disturbances unrelated to metal pollution, including changes in the Po River flow rate and temporary reductions in eutrophication pressure (OcchipintiAmbrogi et al. 2005; Mozetič et al. 2010; Djakovac et al. 2012), filtered native and non-indigenous species. The hypoxia-tolerant $A$. transversa thrived, finally reached reproductive size and established large self-sustaining populations, triggering the first detection.

Our study provides strong evidence that in ecosystems subject to multiple disturbances, invasion success can be difficult to predict because it is the outcome of the complex interplay between multiple selection regimes. Disturbance can shift such regimes even beyond non-indigenous species tolerance limits, causing significant time lags in establishment.

Quantification of time lags enables proper vector identification

Correct placement in time of the arrival and establishment of $A$. transversa enables the reliable identification of the dispersal vector. Juvenile A. transversa can secrete byssus and attach to hard objects such as rocks and shells (Solustri et al. 2003). Therefore, the transfer of mussels and other aquaculture products from Turkey to northern Adriatic countries could have been an effective primary vector of dispersal. Based on our reconstructed history of the A. transversa introduction, we reject this hypothesis because mussel farming started in Turkey only in the 1990s (FAO
2005), ca. 20 years after the first introduction in the Adriatic Sea. Importantly, this hypothesis could not have been rejected assuming the year of first record (the 2000) as the year of first introduction. Most probably, the primary vector of dispersal is shipping, either as larvae in ballast water or as fouling. The analysis of ship traffic time series from 2000 to 2015 of the port of Ravenna (a few kilometers from the study site) shows that two to three hundred ships per year came from Turkey (6-9\% of total traffic), of which $40 \%$ came from Izmir.

\section{Lag times in first detection}

Because most non-indigenous species (NIS) introductions in the sea are unintentional, the initial invasion stages (Blackburn et al. 2011) are rarely observed and the timing of first introduction is generally not known. Occasionally, the first arrival of NIS is backdated based on findings of specimens of known collection date in museums or private collections [e.g., a time lag of 25 years was quantified for the lessepsian fish Fistularia commersonii (Bariche et al. 2014) and of 150 years for the brackish water bivalve Mytilopsis leucophaeata in Great Britain (Oliver 2015)]. Although these findings are precious for the reconstruction of invasion history, they are based on serendipitous events and not on a reproducible method, hindering any large-scale assessment of detection lags, their causes and consequences.

Here we used the subfossil record preserved in sediment cores to show that the first occurrence of $A$. transversa in the northern Adriatic Sea dates back to the 1970s. This is a time lag in first detection of about 25 years, almost double its history after detection. This lag corresponds to the lengthy duration of its introduction phase: the species was then detected as soon as it established. The lack of appreciation of time lags causes the underestimation of the potential consequences of a particular invasion. This, in turn, can impair accurate risk assessment because the time since introduction is the best predictor of the global geographic range of marine invaders (Crooks et al. 2011; Byers et al. 2015). Finally, underestimated introduction modalities delay action by decision makers in defining priorities and setting prevention measures (Belmaker et al. 2009).

Our data show that for $\sim 25$ years, A. transversa remained very small (median size $\leq 5 \mathrm{~mm}$ ) and with 
very limited population size. Combined, these two factors hampered its detection. Low detectability has certainly been coupled with a limited specific monitoring effort. Indeed, the first record occurred in the context of surveys with hydraulic dredges to evaluate stocks of edible clams (Morello and Solustri 2001), where the minimum mesh size used was $6 \mathrm{~mm}$, but most often 12 or even $40 \mathrm{~mm}$ (Morello et al. 2004). The first recorded specimens were between 10 and $31 \mathrm{~mm}$ in size (median: $21 \mathrm{~mm}$ ). Ultimately, the large size of the specimens also facilitated species identification by non-specialists.

Beyond the time impediment

The differential role of disturbance on the early versus late stages of invasions is rarely captured along the entire introduction history of an invader (Clark and Johnston 2011; Clark et al. 2013), and retrieving data on pre-disturbance environmental conditions is difficult (Byers 2002). Our study demonstrates that death assemblages enable reconstructing the invasion history and the time variation of environmental variables at decadal time scales and with almost yearly temporal resolution. Indeed, we were able to identify disturbance-driven shifts in selection regimes, the responses of native and non-indigenous species and the underlying biological mechanisms; we also quantified time lags in first detection and establishment. We suggest that death assemblages will prove precious also in addressing other fundamental issues in invasion ecology, such as disclosing the status of cryptogenic species [whose status as native or non-native is not known (Carlton 1996)] and discriminating pseudoindigenes [introduced species which are mistakenly considered as natives (Carlton 2009)] from true native species (Van Leeuwen et al. 2005, 2008; Coffey et al. 2011).

Death assemblages are a still under-exploited but extremely promising source of information to provide a new perspective on biological invasions and their histories, guaranteeing standardized approaches and quantitative measurements.

Acknowledgements This study is conducted in the framework of the project 'Historical ecology of the northern Adriatic Sea' funded by the Austrian Science Fund (FWF Project P24901, PI: M. Zuschin). PGA is supported by the grant of the Austrian Science Fund (FWF) P 28983-829 'Historical ecology of Lessepsian migration' (PI: P.G. Albano). We thank
Darrell S. Kaufman and Katherine E. Whitacre, Northern Arizona University, for their contribution to amino acid racemization dating, Daniele Cassin and Roberto Zonta, CNRISMAR in Venice, for pollutant analyses, Jernej Sedmak, captain of the vessel Manta bianca, with which the coring campaign in the Adriatic Sea was conducted and Rafał Nawrot for discussions. Danae Thivaiou, Elena Turac and Sabine Maria Handler helped in measuring shells. Two anonymous reviewers are acknowledged for their constructive criticism on an earlier version of the manuscript. Open access funding provided by Austrian Science Fund (FWF).

Open Access This article is distributed under the terms of the Creative Commons Attribution 4.0 International License (http:// creativecommons.org/licenses/by/4.0/), which permits unrestricted use, distribution, and reproduction in any medium, provided you give appropriate credit to the original author(s) and the source, provide a link to the Creative Commons license, and indicate if changes were made.

\section{References}

Albano PG, Rinaldi E, Evangelisti F et al (2009) On the identity and origin of Anadara demiri (Bivalvia: arcidae). J Mar Biol Assoc UK 89:1289-1298. https://doi.org/10.1017/ S0025315409000551

Allen AP, Kosnik MA, Kaufman DS (2013) Characterizing the dynamics of amino acid racemization using time-dependent reaction kinetics: a Bayesian approach to fitting agecalibration models. Quat Geochronol 18:63-77. https://doi. org/10.1016/j.quageo.2013.06.003

Anderson MJ (2001) A new method for non-parametric multivariate analysis of variance. Austral Ecol 26:32-46. https:// doi.org/10.1111/j.1442-9993.2001.01070.pp.x

Bariche M, Kazanjian G, Azzurro E (2014) A lag of 25 years: evidence from an old capture of Fistularia commersonii Rüppell, 1838 from Lebanon (Mediterranean Sea). J Appl Ichthyol 30:535-536. https://doi.org/10.1111/jai.12394

Barker S, Broecker W, Clark E, Hajdas I (2007) Radiocarbon age offsets of foraminifera resulting from differential dissolution and fragmentation within the sedimentary bioturbated zone. Paleoceanography 22:PA2205. https://doi.org/ 10.1029/2006PA001354

Belmaker J, Brokovich E, China V et al (2009) Estimating the rate of biological introductions: lessepsian fishes in the Mediterranean. Ecology 90:1134-1141. https://doi.org/10. 1890/07-1904.1

Blackburn TM, Pyšek P, Bacher S et al (2011) A proposed unified framework for biological invasions. Trends Ecol Evol 26:333-339. https://doi.org/10.1016/j.tree.2011.03. 023

Boening DW (2000) Ecological effects, transport, and fate of mercury: a general review. Chemosphere 40:1335-1351. https://doi.org/10.1016/S0045-6535(99)00283-0

Broom MJ (1985) The biology and culture of marine bivalve molluscs of the genus Anadara. WorldFish

Bryan GW, Langston WJ (1992) Bioavailability, accumulation and effects of heavy metals in sediments with special 
reference to United Kingdom estuaries: a review. Environ Pollut 76:89-131. https://doi.org/10.1016/02697491(92)90099-V

Burton GA (2002) Sediment quality criteria in use around the world. Limnology 3:65-76. https://doi.org/10.1007/ s102010200008

Byers JE (2000) Differential susceptibility to hypoxia aids estuarine invasion. Mar Ecol Prog Ser 203:123-132. https://doi.org/10.3354/meps203123

Byers JE (2002) Impact of non-indigenous species on natives enhanced by anthropogenic alteration of selection regimes. Oikos 97:449-458. https://doi.org/10.1034/j.1600-0706. 2002.970316.x

Byers JE, Smith RS, Pringle JM et al (2015) Invasion expansion: time since introduction best predicts global ranges of marine invaders. Sci Rep 5:12436. https://doi.org/10.1038/ srep12436

Carlton JT (1996) Biological invasions and cryptogenic species. Ecology 77:1653-1655. https://doi.org/10.2307/2265767

Carlton JT (2009) Deep invasion ecology and the assembly of communities in historical time. In: Biological invasions in marine ecosystems. Springer, Berlin, pp 13-56

Chardy P, Guillaumont B, Hamon D (1984) Étude dynamique de la population de Nucula nucleus (Bivalve, Protobranche) du cap de Flamanville (Manche). Oceanol Acta 7:103-112

Chiantore M, Bedulli D, Cattaneo-Vietti R et al (2001) Long term changes in the Mollusc-Echinoderm assemblages in the North and Coastal Middle Adriatic Sea. Atti Ital Ocean Limn 14:63-75

Clark GF, Johnston EL (2011) Temporal change in the diversity-invasibility relationship in the presence of a disturbance regime. Ecol Lett 14:52-57. https://doi.org/10.1111/ j.1461-0248.2010.01550.x

Clark GF, Johnston EL, Leung B (2013) Intrinsic time dependence in the diversity-invasibility relationship. Ecology 94:25-31. https://doi.org/10.1890/12-0592.1

Clarke KR (1993) Non-parametric multivariate analyses of changes in community structure. Aust J Ecol 18:117-143. https://doi.org/10.1111/j.1442-9993.1993.tb00438.x

Coffey EED, Froyd CA, Willis KJ (2011) When is an invasive not an invasive? Macrofossil evidence of doubtful native plant species in the Galápagos Islands. Ecology 92:805-812. https://doi.org/10.1890/10-1290.1

Cohen AN, Carlton JT (1998) Accelerating invasion rate in a highly invaded estuary. Science 279:555-558. https://doi. org/10.1126/science.279.5350.555

Crema R, Castelli A, Prevedelli D (1991) Long term eutrophication effects on macrofaunal communities in northern Adriatic Sea. Mar Pollut Bull 22:503-508. https://doi.org/ 10.1016/0025-326X(91)90405-H

Crocetta F (2011) Marine alien Mollusca in the Gulf of Trieste and neighbouring areas: a critical review and state of knowledge (updated in 2011). Acta Adriat 52:247-260

Crocetta F (2012) Marine alien Mollusca in Italy: a critical review and state of the knowledge. J Mar Biol Assoc UK 92:1357-1365

Crooks JA, Chang AL, Ruiz GM (2011) Aquatic pollution increases the relative success of invasive species. Biol Invasions 13:165-176. https://doi.org/10.1007/s10530010-9799-3
Dauvin J-C, Gentil F (1989) Long-term changes in populations of subtidal bivalves (Abra alba and A. prismatica) from the Bay of Morlaix (Western English Channel). Mar Biol 103:63-73. https://doi.org/10.1007/BF00391065

Diaz RJ, Rosenberg R (1995) Marine benthic hypoxia: a review of its ecological effects and the behavioural responses of benthic macrofauna. Oceanogr Mar Biol Annu Rev 33:245-303

Dietl GP, Flessa KW (2011) Conservation paleobiology: putting the dead to work. Trends Ecol Evol 26:30-37. https://doi. org/10.1016/j.tree.2010.09.010

Dietl GP, Kidwell SM, Brenner M, et al (2015) Conservation paleobiology: leveraging knowledge of the past to inform conservation and restoration. In: Httpdxdoiorg101146annurev-Earth-040610-133349. http://www.annualreviews. org/doi/10.1146/annurev-earth-040610-133349. Accessed 3 Mar 2017

Djakovac T, Degobbis D, Supić N, Precali R (2012) Marked reduction of eutrophication pressure in the northeastern Adriatic in the period 2000-2009. Estuar Coast Shelf Sci 115:25-32. https://doi.org/10.1016/j.ecss.2012.03.029

Djakovac T, Supić N, Bernardi Aubry F et al (2015) Mechanisms of hypoxia frequency changes in the northern Adriatic Sea during the period 1972-2012. J Mar Syst 141:179-189. https://doi.org/10.1016/j.jmarsys.2014.08. 001

Elton CS (1958) The ecology of invasions by animals and plants. Methuen, London

FAO (2005) National aquaculture sector overview, Turkey

Gallmetzer I, Haselmair A, Stachowitsch M, Zuschin M (2016) An innovative piston corer for large-volume sediment samples. Limnol Oceanogr Methods 14:698-717. https:// doi.org/10.1002/lom3.10124

Gallmetzer I, Haselmair A, Tomašových A et al (2017) Responses of molluscan communities to centuries of human impact in the northern Adriatic Sea. PLoS ONE 12:e180820. https://doi.org/10.1371/journal.pone. 0180820

Ghisotti F, Rinaldi E (1976) Osservazioni sulla popolazione di Scapharca, insediatasi in questi ultimi anni su un tratto del litorale romagnolo. Conchiglie 12:183-195

Giani M, Djakovac T, Degobbis D et al (2012) Recent changes in the marine ecosystems of the northern Adriatic Sea. Estuar Coast Shelf Sci 115:1-13. https://doi.org/10.1016/j. ecss.2012.08.023

Holmes SP, Miller N (2006) Aspects of the ecology and population genetics of the bivalve Corbula gibba. Mar Ecol Prog Ser 315:129-140

Hrs-Brenko M (2006) The basket shell, Corbula gibba Olivi, 1792 (Bivalve Mollusks) as a species resistant to environmental disturbances: a review. Acta Adriat 47:49-64

Jensen JN (1990) Increased abundance and growth of the suspension-feeding bivalve corbula gibba in a shallow part of the eutrophic Limfjord, Denmark. Neth J Sea Res 27:101-108. 7579(90)90038-I

Jewett EB, Hines AH, Ruiz GM (2005) Epifaunal disturbance by periodic low levels of dissolved oxygen: native vs. invasive species response. Mar Ecol Prog Ser 304:31-44. https:// doi.org/10.3354/meps304031 
Johannessen SC, Macdonald RW (2012) There is no 1954 in that core! Interpreting sedimentation rates and contaminant trends in marine sediment cores. Mar Pollut Bull 64:675-678

Justić D (1991) Hypoxic conditions in the northern Adriatic Sea: historical development and ecological significance. Geol Soc Spec Publ 58:95-105. https://doi.org/10.1144/GSL. SP.1991.058.01.07

Kaufman DS, Manley WF (1998) A new procedure for determining DL amino acid ratios in fossils using reverse phase liquid chromatography. Quat Sci Rev 17:987-1000. https:// doi.org/10.1016/S0277-3791(97)00086-3

Kidwell SM, Tomašových A (2013) Implications of time-averaged death assemblages for ecology and conservation biology. Annu Rev Ecol Evol Syst 44:539-563

Kosnik MA, Kaufman DS (2008) Identifying outliers and assessing the accuracy of amino acid racemization measurements for geochronology: II. Data screening. Quat Geochronol 3:328-341. https://doi.org/10.1016/j.quageo. 2008.04.001

Kosnik MA, Kowalewski M (2016) Understanding modern extinctions in marine ecosystems: the role of palaeoecological data. Biol Lett 12:20150951. https://doi.org/10. 1098/rsbl.2015.0951

Kowalewski M, Wittmer JM, Dexter TA et al (2015) Differential responses of marine communities to natural and anthropogenic changes. Proc R Soc Lond B Biol Sci 282:20142990. https://doi.org/10.1098/rspb.2014.2990

Kruskal JB, Wish M (1978) Multidimensional scaling. Number 07-011 in Sage University Paper series on quantitative applications in the social sciences. Sage Publications, Beverly Hills

Lagos ME, Barneche DR, White CR, Marshall DJ (2017) Do low oxygen environments facilitate marine invasions? Relative tolerance of native and invasive species to low oxygen conditions. Glob Change Biol. https://doi.org/10. $1111 /$ gcb. 13668

McArdle BH, Anderson MJ (2001) Fitting multivariate models to community data: a comment on distance-based redundancy analysis. Ecology 82:290-297. https://doi.org/10. 2307/2680104

McGreer ER (1979) Sublethal effects of heavy metal contaminated sediments on the bivalve Macoma balthica (L.). Mar Pollut Bull 10:259-262. https://doi.org/10.1016/0025326X(79)90482-X

McGreer ER (1982) Factors affecting the distribution of the bivalve, Macoma balthica (L.) on a mudflat receiving sewage effluent, Fraser river estuary, British Columbia. Mar Environ Res 7:131-149. https://doi.org/10.1016/ 0141-1136(82)90038-1

Mikkelsen PM, Bieler R (2008) Seashells of Southern Florida: living marine Mollusks of the Florida keys and adjacent Regions. Princeton University Press, Princeton

Miller GH, Kaufman DS, Clarke SJ (2013) Amino acid dating. In: Elias SA, Mock CJ (eds) Encyclopedia of quaternary science, 2nd edn. Elsevier, Amsterdam, pp 37-48

Mizzan L (2002) Anadara demirii (Piani, 1981) (Mollusca Bivalvia Arcidae). Boll Mus Civ Storia Nat Venezia 53:265-266
Morello E, Solustri C (2001) First record of Anadara demiri (Piani, 1981) (Bivalvia: Arcidae). Boll Malacol 37:231-234

Morello EB, Solustri C, Froglia C (2004) The alien bivalve Anadara demiri (Arcidae): a new invader of the Adriatic Sea, Italy. J Mar Biol Assoc UK 84:1057-1064. https://doi. org/10.1017/S0025315404010410h

Mozetič P, Solidoro C, Cossarini G et al (2010) Recent trends towards oligotrophication of the Northern Adriatic: evidence from chlorophyll a time series. Estuaries Coasts 33:362-375. https://doi.org/10.1007/s12237-009-9191-7

Nerlović V, Doğan A, Hrs-Brenko M (2011) Response to oxygen deficiency (depletion): bivalve assemblages as an indicator of ecosystem instability in the northern Adriatic Sea. Biologia (Bratisl) 66:1114-1126

Occhipinti-Ambrogi A, Savini D (2003) Biological invasions as a component of global change in stressed marine ecosystems. Mar Pollut Bull 46:542-551. https://doi.org/10.1016/ S0025-326X(02)00363-6

Occhipinti-Ambrogi A, Favruzzo M, Savini D (2002) Multiannual variations of macrobenthos along the Emilia-Romagna coast (Northern Adriatic). Mar Ecol 23:307-319

Occhipinti-Ambrogi A, Savini D, Forni G (2005) Macrobenthos community structural changes off Cesenatico coast (Emilia Romagna, Northern Adriatic), a six-year monitoring programme. Sci Total Environ 353:317-328. https://doi.org/ 10.1016/j.scitotenv.2005.09.021

Occhipinti-Ambrogi A, Marchini A, Cantone G et al (2011) Alien species along the Italian coasts: an overview. Biol Invasions 13:215-237. https://doi.org/10.1007/s10530010-9803-y

Oliver PG (2015) Old shell collection casts new light on an alien species. The dark false mussel (Mytilopsis leucophaeata) may have been in Britain as early as 1800! J Conchol 42:1

Piola RF, Johnston EL (2008) Pollution reduces native diversity and increases invader dominance in marine hard-substrate communities. Divers Distrib 14:329-342. https://doi.org/ 10.1111/j.1472-4642.2007.00430.x

Rachor E, Salzwedel H (1976) Studies on population dynamics and productivity of some bivalves in the German Bight. In: Proceedings of 10th European marine biology symposium, pp 575-588

Riedel B, Zuschin M, Stachowitsch M (2012) Tolerance of benthic macrofauna to hypoxia and anoxia in shallow coastal seas: a realistic scenario. Mar Ecol Prog Ser 458:39-52. https://doi.org/10.3354/meps09724

Riedel B, Pados T, Pretterebner K et al (2014) Effect of hypoxia and anoxia on invertebrate behaviour: ecological perspectives from species to community level. Biogeosciences 11:1491-1518. https://doi.org/10.5194/bg-11-1491-2014

Rinaldi E (2001) Segnalazioni faunistiche n. 41-43. Anadara demiri (Piani, 1981). Quad Studi E Not Storia Nat Della Romagna 14:127

Roper DS, Nipper MG, Hickey CW et al (1995) Burial, crawling and drifting behaviour of the bivalve Macomona liliana in response to common sediment contaminants. Mar Pollut Bull 31:471-478. https://doi.org/10.1016/0025326X(96)81928-X

Sanchez-Cabeza JA, Ruiz-Fernández AC (2012) ${ }^{210} \mathrm{~Pb}$ sediment radiochronology: an integrated formulation and 
classification of dating models. Geochim Cosmochim Acta 82:183-200. https://doi.org/10.1016/j.gca.2010.12.024

Shepard FP (1954) Nomenclature based on sand-silt-clay ratios. J Sediment Res 24:151-158. https://doi.org/10.1306/ D4269774-2B26-11D7-8648000102C1865D

Solustri C, Morello EB, Froglia C (2003) Osservazioni su Anadara demiri (Piani, 1981) (Bivalvia: Arcidae) epibionte di alcune specie di molluschi. Biol Mar Mediterr 10:622-625

Strathmann MF (1987) Reproduction and development of marine invertebrates of the Northern Pacific Coast. University of Washington Press, Washington

Streftaris N, Zenetos A (2006) Alien marine species in the Mediterranean-the 100 "Worst Invasives" and their Impact. Mediterr Mar Sci 7:87-118. https://doi.org/10. 12681/mms. 180

Tomašových A, Kidwell SM, Barber RF (2015) Inferring skeletal production from time-averaged assemblages: skeletal loss pulls the timing of production pulses towards the modern period. Paleobiology 42:54-76. https://doi.org/ 10.1017/pab.2015.30
Tomašových A, Gallmetzer I, Haselmair A et al (2017) Stratigraphic unmixing reveals repeated hypoxia events over the past 500 year in the northern Adriatic Sea. Geology G38676:1. https://doi.org/10.1130/G38676.1

Van Leeuwen JFN, Schaefer H, Van der Knaap WO et al (2005) Native or introduced? Fossil pollen and spores may say. An example from the Azores Islands. Neobiota 6:27-34

van Leeuwen JFN, Froyd CA, van der Knaap WO et al (2008) Fossil pollen as a guide to conservation in the Galápagos. Science 322:1206. https://doi.org/10.1126/science. 1163454

Varó I, Redón S, Garcia-Roger EM et al (2015) Aquatic pollution may favor the success of the invasive species $A$. franciscana. Aquat Toxicol 161:208-220. https://doi.org/ 10.1016/j.aquatox.2015.02.008

Walker RL, Power AJ (2003) Growth and gametogenic cycle of the transverse ark, Anadara transversa (Say, 1822), in coastal Georgia. Am Malacol Bull 18:55-60

Weis JS (2014) Physiological, developmental and behavioral effects of marine pollution. Springer, London 